\title{
GENE-PROTEIN RELATIONSHIPS IN ACETATE-REQUIRING MUTANTS OF NEUROSPORA CRASSA DEFICIENT IN ACTIVITY OF PYRUVATE DEHYDROGENASE COMPLEX
}

\author{
RYOSUKE OKUMURA AND HOMARE KUWANA ${ }^{1)}$ \\ Faculty of Science, Kwansei Gakuin University, \\ Nishinomiya, Hyogo-ken 662
}

Received April 18, 1979

\begin{abstract}
Three groups of acetate-requiring mutants of Neurospora crassa, $a c e-2, a c e-3$ and $a c e-4$, were found to lack pyruvate dehydrogenase complex (PDHC) activity. Gene-protein relationships in these mutants were investigated. All heterokaryons composed of inter-genic combinations exhibited PDHC activity. In addition, two ace-4 mutants complemented in vivo. On the other hand, in vitro complementation of PDHC activity by simple mixing two extracts was detected only in combinations of ace-2 +ace-4 and ace-3+ace-4. Each of the three component enzymes of PDHC was detected as two peaks by Sephadex G-200 gel chromatography. One of them eluted from Sephadex column at void volume comprises high molecular weight aggregate. In the case of the wild-type strain, it may be PDHC itself. The other peak comprises the activity due to free component enzyme. Molecular weights of pyruvate dehydrogenase (PDHase), lipoate acetyltransferase (LATase) and lipoamide reductase (LiRase) in free states were estimated at 190,000, 300,000 and 110,000, respectively. Mutations in ace-4 gene affect LATase not to aggregate to form the core of PDHC. As a result, ace-4 mutants show high activities of free component enzymes, PDHase and LiRase. Mutants of $a c e-2$ and $a c e-3$ genes have the activities of all the three component enzymes of PDHC. Correspondence between ace-2 and ace-3 genes and component enzymes of PDHC could not be determined.
\end{abstract}

\section{INTRODUCTION}

Pyruvate dehydrogenase complex (PDHC) has been isolated as a multienzyme complex from Escherichia coli (Koike et al. 1960, 1963; Eley et al. 1972) and mammalian mitochondria (Hayakawa et al. 1969; Barrera et al. 1972) and studied in full detail. PDHC consists of three enzyme components: pyruvate dehydrogenase (PDHase, EC 1.2.4.1), lipoate acetyltransferase (LATase, EC 2.3.1.12) and lipoamide reductase (LiRase,

1) Correspondence should be made to H. Kuwana. 
EC 1.6.4.3). Similar PDHC has been isolated from Saccharomyces cerevisiae (Wais et al. 1973) and Neurospora crassa (Harding et al. 1970; Wieland et al. 1972). The size and structure of the PDHC from $N$. crassa has been studied by electron microscopy and ultracentrifugation (Harding et al. 1970). Regulatory kinase and phosphatase subunits are also included in PDHC of $N$. crassa (Wieland et al. 1972).

Investigation of PDHC from genetic viewpoint has been reported in E. coli (Guest 1974) and in Salmonella typhimurium (Langley and Guest 1974). In these bacteria, the structural genes of the three component enzymes are arranged contiguously one another, and seem to form ace operon. In the case of eukaryote, two unlinked genes for PDHC have been reported in Aspergillus nidulans (Payton et al. 1977).

In the preceding paper, we have reported genetic studies of seven acetate genes in N. crassa (Kuwana and Okumura 1979). This paper deals with complementation and gene-protein relationships in the acetate mutants deficient in PDHC activity.

\section{MATERIALS AND METHODS}

The strains of Neurospora crassa, used in the present study have been described in the preceding paper (Kuwana and Okumura 1979). In oder to obtain mycelium for enzyme assay, the wild type strain, $\mathrm{KGa}$, was grown at $34^{\circ} \mathrm{C}$ for one day in Vogel's minimal medium (Vogel 1964), with $2 \%$ sucrose or with $2 \%$ sucrose plus $0.3 \%$ sodium acetate. Culture was aerated with an air pump for tropical fish culture. Acetate mutants were grown for 3 to 5 days with $2 \%$ sucrose plus $0.3 \%$ acetate. Usually, starvation culture was performed, because PDHC was repressed by acetate and acetate mutants require acetate for growth. The mycelium grown on acetate-supplemented medium was transferred to minimal medium and was incubated again.

Sodium pyruvate, $\mathrm{NAD}^{+}, \mathrm{NADH}$ and ATP were products of Wako Pure Chemical Industries, Ltd., coenzyme A (CoA), acetylphosphate and phosphotransacetylase of Boeringer-Mannheim GmbH, and DL-lipoamide of Sigma Chemical Co. DL-dihydrolipoamide was synthesized from DL-lipoamide by the method described by Reed et al. (1958).

All preparations for enzymes were carried out at near $0^{\circ} \mathrm{C}$.

Preparation of PDHC. PDHC was prepared in two ways. Mitochondrial 50,000$220,000 \times g$ precipitate (M5-22P) was prepared as follows. Mycelium was ground with an equal weight of acid-washed sand and 3 to 5 volumes of grinding buffer, which contained $0.25 \mathrm{M}$ sucrose, $0.043 \mathrm{mM}$ thiamine pyrophosphate (TPP), $0.4 \mathrm{mM} \mathrm{MnSO}_{4}, 5.3 \mathrm{mM}$ L-cysteine and $0.15 \%$ bovine serum albumin (BSA) in $0.02 \mathrm{M}$ potassium phosphate buffer, $\mathrm{pH}$ 7.5. The homogenate was squeezed through gauze, and the filtrate was centrifuged at $1,000 \times g$ for $15 \mathrm{~min}$. The supernatant was then centrifuged at $10,000 \times g$ for $20 \mathrm{~min}$. Resulted pellet was washed once with the grinding buffer. Washed mitochondrial pellet was suspended in $0.1 \mathrm{M}$ Tris- $\mathrm{HCl}$ buffer, $\mathrm{pH} 7.8$, containing $0.1 \mathrm{M}$ sucrose. This suspension was sonicated using Tomy model UR-150P sonicator for $20 \mathrm{sec}$ with a setting of $5.5 \mathrm{~A}$, and centrifuged at $50,000 \times g$ for $20 \mathrm{~min}$. The supernatant (M5S) was centrifuged at $220,000 \times g$, for $20 \mathrm{~min}$ again. The pellet was suspended in $0.02 \mathrm{M}$ potassium 
phosphate buffer, $\mathrm{pH} 7.0$, containing $2 \mathrm{mM}$ dithiothreitol, $0.5 \mathrm{mM}$ TPP and $0.5 \mathrm{mM}$ $\mathrm{MnSO}_{4}$ (DTT buffer). This suspension is M5-22P for PDHC assay.

Crude $50,000-220,000 \times g$ precipitate $(\mathrm{C} 5-22 \mathrm{P})$ was prepared as follows. The first $10,000 \times g$ supernatant described above was centrifuged at $50,000 \times g$ for $20 \mathrm{~min}$ and this supernatant (C5S) was again centrifuged at $220,000 \times g$ for $20 \mathrm{~min}$. Resulted pellet was suspended in DTT buffer. This suspension is C5-22P for PDHC assay.

Preparation of component enzymes of PDHC. M5S, M5-22P and M22S fractions were prepared as follows. Mycelium was ground with sand in BSA buffer, which contained $0.25 \mathrm{M}$ sucrose and $0.15 \% \mathrm{BSA}$ in $0.02 \mathrm{M}$ potassium phosphate buffer, pH 7.5. From this homogenate, mitochondrial pellet was obtained by the same procedure as described in preparation of PDHC. The pellet was suspended in $0.02 \mathrm{M}$ potassium phosphate buffer, $\mathrm{pH} 7.5$, and sonicated as described above. This suspension was centrifuged at $50,000 \times g$ for $20 \mathrm{~min}$. The supernatant was used as mitochondrial $50,000 \times g$ supernatant (M5S) for LATase assay. This supernatant was centrifuged at $220,000 \times g$ for $20 \mathrm{~min}$. The pellet was suspended in $0.02 \mathrm{M}$ potassium phosphate buffer, $\mathrm{pH} 7.5$, and was used as mitochondrial $50,000-220,000 \times g$ pellet (M5-22P). The supernatant was used as mitochondrial $220,000 \times g$ supernatant (M22S). M5-22P and M22S were used for PDHase and LiRase assays.

Sephadex G-200 gel chromatography. Sephadex G-200 (Pharmacia, Inc.) was soaked in $0.02 \mathrm{M}$ potassium phosphate buffer, $\mathrm{pH} 7.5$, for 2 weeks. A $2.6 \times 45 \mathrm{~cm}$ column was packed with about $240 \mathrm{ml}$ of the Sephadex and equilibrated with the same buffer. The sample for Sephadex G-200 gel chromatography was prepared by grinding mycelium with sand in $0.02 \mathrm{M}$ potassium phosphate buffer, $\mathrm{pH} 7.5$. The homogenate was centrifuged at $50,000 \times g$ for $20 \mathrm{~min}$. From 2.5 to $5 \mathrm{ml}$ of this supernatant was applied to the Sephadex column. This fraction contained not only PDHC but also three component enzymes of PDHC. Elution was carried out with the same buffer and eluate was fractionated by $4.5 \mathrm{ml}$. Blue-Dextran 2000 (Pharmacia, Inc.) was used to determine the void volume. The position of a protein in eluate was varied slightly with columns.

Enzyme assay. PDHC activity was measured by monitoring NADH formation spectrophotometrically at $340 \mathrm{~nm}$ as described by Harding et al. (1970). Specific activity of PDHC was expressed as $\mu$ moles $\mathrm{NADH}$ per mg protein per hour.

PDHase assay was based on colorimetric determination of ferrocyanide produced by oxidative decarboxylation of pyruvate with ferricyanide as electron acceptor (Reed and Willms 1966), except that $0.5 \mathrm{M}$ sodium pyruvate was used for the substrate. Specific activity was expressed as $\mu$ moles pyruvate per mg protein per hour.

LATase activity was measured by the method of Reed and Willms (1966). A standard curve was perpared with acetylphosphate (Lipmann and Tuttle 1945), instead of S-acetyldihydrolipoamide. Specific activity was expressed as $\mu$ moles S-acetyldihydrolipoamide per $\mathrm{mg}$ protein per hour.

LiRase activity was determined by the method of Reed and Willms (1966). The assay was based on spectrophotometric determinantion of the rate of NADH oxidation in the presence of DL-lipoamide at pH 6.3 (lipoamide-NADH system). The assay based 
on reverse reaction was also used in the presence of DL-dihydrolipoamide and $\mathrm{NAD}^{+}$ at $\mathrm{pH} 7.5$ (dihydrolipoamide- $\mathrm{NAD}^{+}$system). Specific activity was expressed as $\mu$ moles NADH per mg protein per hour.

PDHC and LiRase assays were carried out at $30^{\circ} \mathrm{C}$, and PDHase and LATase assays at $37^{\circ} \mathrm{C}$.

Protein was determined by the method of Lowry et al. (1951).

Complementation tests. Complementation in growth was tested on minimal agar plate at the center of which a drop of conidial suspension was inoculated singly or in combination. Surpassing hyphal extension from combined inoculum over that from single inoculum was taken as positive complementation.

In vivo complementation of PDHC activity was determined using heterokaryotic mycelium of two strains. Inoculum cultures of two strains were added together to liquid Vogel's minimal medium and cultivated under aeration at $34^{\circ} \mathrm{C}$ for 3 to 5 days.

The ability to complement in vitro was tested by looking for the appearance of PDHC activity when cell-free extracts of mutants were mixed in combinations. The C5-22P fraction was prepared from the mixture of C5S fractions of two strains. The M5-22P fraction was prepared from the mixture of M5S fractions of two strains. Both the C5-22P and M5-22P fractions were used for the enzyme assay.

\section{RESULTS}

Characterization of PDHC. The maximum activity of PDHC was obtained 10 hours after transferring the mycelium from acetate-supplemented medium to minimal medium in both the wild type strain, $\mathrm{KGa}$, and the acetate-requiring strain, 512a (ace-5) (Fig. 1).

The optimum $\mathrm{pH}$ of $\mathrm{PDHC}$ of the wild type was 7.7 using Tris- $\mathrm{HCl}$ buffer and potassium phosphate buffer. The $\mathrm{Km}$ values for pyruvate, $\mathrm{CoA}$ and $\mathrm{NAD}^{+}$were

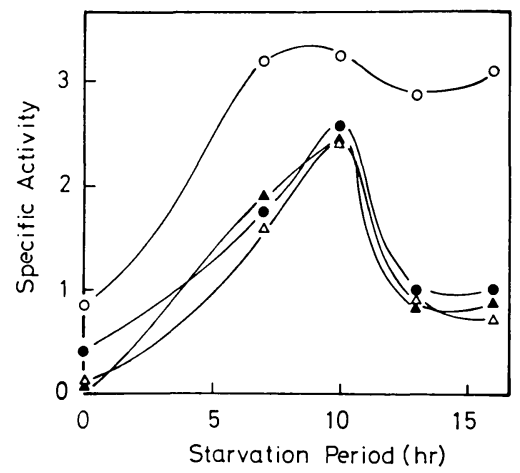

Fig. 1. Effect of starvation period on PDHC activity. The mycelium grown in Vogel's minimal medium supplemented with acetate was transferred to minimal medium and PDHC was extracted at the indicated time. $\mathrm{O}, \mathrm{M} 5-22 \mathrm{P}$ of $\mathrm{KGa}$ (wild type); C5-22P of KGa; $\triangle$, M5-22P of 512a $($ ace-5); $\Delta, \mathrm{C} 5-22 \mathrm{P}$ of 512a. 
Table 1. Activity of PDHC in various strains

\begin{tabular}{|c|c|c|}
\hline Strain (Genotype) & \multicolumn{2}{|c|}{$\begin{array}{l}\text { Specific activity } \\
(\mu \mathrm{mole} / \mathrm{mg} \text { protein } / \mathrm{h})\end{array}$} \\
\hline & M5-22P & C5-22P \\
\hline Y2492a $\quad($ ace-1) & 1.1 & 0.4 \\
\hline $511 \mathrm{a} \quad(a c e-2)$ & 0 & 0 \\
\hline $526 \mathrm{a} \quad(\prime \prime)$ & 0 & 0.2 \\
\hline $536 \mathrm{a} \quad($ ace -3$)$ & 0 & 0 \\
\hline $508 \mathrm{a} \quad($ ace -4$)$ & 0 & 0 \\
\hline $523 a \quad(\prime \prime)$ & 0 & 0 \\
\hline$(a c e-5)$ & 2.3 & 2.5 \\
\hline $513 a \quad(" \prime)$ & 0.7 & \\
\hline$(a c e-6=s u c)$ & 0.7 & 0.3 \\
\hline $510 \mathrm{a} \quad(" \prime)$ & 0.6 & \\
\hline $539 \mathrm{a} \quad($ ace -7$)$ & 1.3 & \\
\hline (wild type) & 3.2 & 0.4 \\
\hline
\end{tabular}

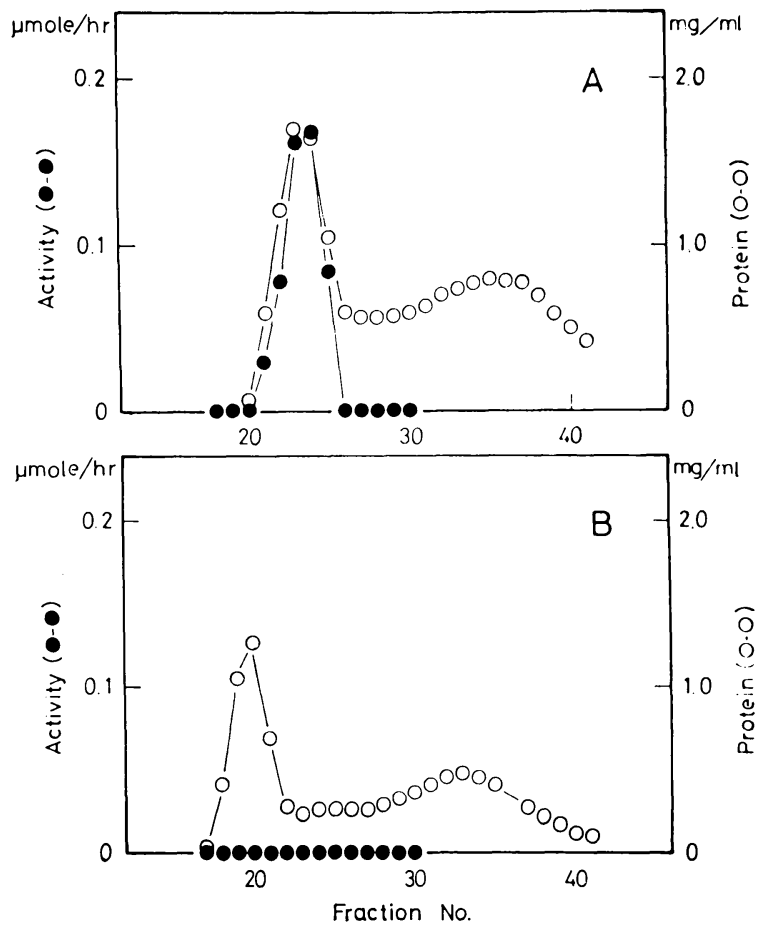

Fig. 2. Elution patterns of PDHC activity from Sephadex G-200 column in $\mathrm{KGa}$ (wild type) (A) and 508a (ace-4) (B). 
$0.29 \mathrm{mM}, 0.013 \mathrm{mM}$ and $0.39 \mathrm{mM}$, respectively. Magnesium ion $\left(\mathrm{Mg}^{2+}\right)$ slightly stimulated PDHC activity at a concentration of $1-10 \mathrm{mM}$, but higher concentration was inhibitory. ATP markedly inhibited PDHC activity. These characteristics are similar to those reported by Harding et al. (1970) and Wieland et al. (1972) on purified PDHC preparations of $N$. crassa.

The PDHC activity from mitochondrial extract was unstable. The activity was remained only $10 \%$ of the initial activity after 7.5 hours at $0^{\circ} \mathrm{C}$, while $60 \%$ of the activity was remained after 5 days at $-20^{\circ} \mathrm{C}$. On the other hand, $\mathrm{PDHC}$ from crude extract was very stable. The activity was not lost at least 8 days at both $0^{\circ} \mathrm{C}$ and $-20^{\circ} \mathrm{C}$.

\begin{tabular}{|c|c|c|c|c|c|}
\hline 523 & 508 & 526 & 536 & 511 & \\
\hline- & + & + & + & + & 523 \\
\hline \multirow{2}{*}{} & - & + & + & + & 508 \\
\cline { 2 - 6 } & - & + & - & 526 \\
\cline { 2 - 6 } & \multicolumn{1}{c}{} & - & + & 536 \\
\cline { 2 - 6 }
\end{tabular}

Fig. 3. Results of complementation test in growth of heterokaryon made by pairwise combinations of five acetate mutants. 511a and 526a belong to ace-2, 536a to ace-3, and 508a and 523a to ace-4. + , Complementing; - non-complementing.

Table 2. Restoration of PDHC activity in mixtures of cell-free extracts of PDHC mutants

\begin{tabular}{|c|c|c|}
\hline \multirow{2}{*}{$\begin{array}{c}\text { Combination of strains } \\
\text { (Genotype })\end{array}$} & \multicolumn{2}{|c|}{$\begin{array}{c}\text { Specific activity } \\
(\mu \text { moles } / \text { mg protein } / \mathrm{h})\end{array}$} \\
\hline & M5-22P & $\mathrm{C} 5-22 \mathrm{P}$ \\
\hline 511a $($ ace-2) & 0 & 0 \\
\hline $526 \mathrm{a} \quad($ ace -2$)$ & 0 & 0 \\
\hline $536 \mathrm{a} \quad($ ace -3$)$ & 0 & 0 \\
\hline $508 \mathrm{a} \quad(a c e-4)$ & 0 & 0 \\
\hline $523 \mathrm{a} \quad($ ace -4$)$ & 0 & 0 \\
\hline $511 a+526 a$ & 0 & 0 \\
\hline $511 a+536 a$ & 0 & 0 \\
\hline $526 a+536 a$ & 0 & 0 \\
\hline $508 a+523 a$ & 0 & 0 \\
\hline $511 a+508 a$ & 0.6 & 1.4 \\
\hline $511 a+523 a$ & 0.8 & 0.6 \\
\hline $526 a+508 a$ & 0.2 & 0.6 \\
\hline $526 a+523 a$ & 0.4 & 1.2 \\
\hline $536 a+508 a$ & 0.2 & 0.7 \\
\hline $536 a+523 a$ & 0.2 & 0.6 \\
\hline KGa (wild type) & 3.2 & 0.4 \\
\hline
\end{tabular}


PDHC activity. Activity of PDHC in the wild type and acetate mutant strains is shown in Table 1. Mutants of ace-2, ace-3 and ace-4 genes lack PDHC activity, while the other acetate mutant and the wild type strains definitely showed it.

When extract of the wild type strain, KGa, was subjected to Sephadex G-200 gel chromatography, PDHC activity was obtained at void volume (Fig. 2A), while the activity was not detected in the case of ace-4 strain, 508a (Fig. 2B). The other four strains that belong to ace-2 (511a and 526a), ace-3 (536a) and ace-4 (523a) showed the same elution pattern as strain $508 \mathrm{a}$.

Complementation test. Nine out of ten pairwise combinations of the five acetate mutants deficient in PDHC activity showed positive complementation in growth on minimal medium (Fig. 3). The combination 508a $+523 \mathrm{a}$, both of which belong to ace-4, showed intra-genic complementation. In all the nine cases, PDHC activity was detected in the extracts of the mycelium of heterokaryons grown in liquid minimal medium.

Table 2 shows the results of in vitro complementation of PDHC activity between acetate mutants. The combination $511 \mathrm{a}+526 \mathrm{a}$, which did not complement in vivo, was also not found to restore PDHC activity in vitro. In addition, the combinations $511 \mathrm{a}+536 \mathrm{a}$, $526 \mathrm{a}+536 \mathrm{a}$ and $508 \mathrm{a}+523 \mathrm{a}$, which complemented in vivo, did not complement in vitro.
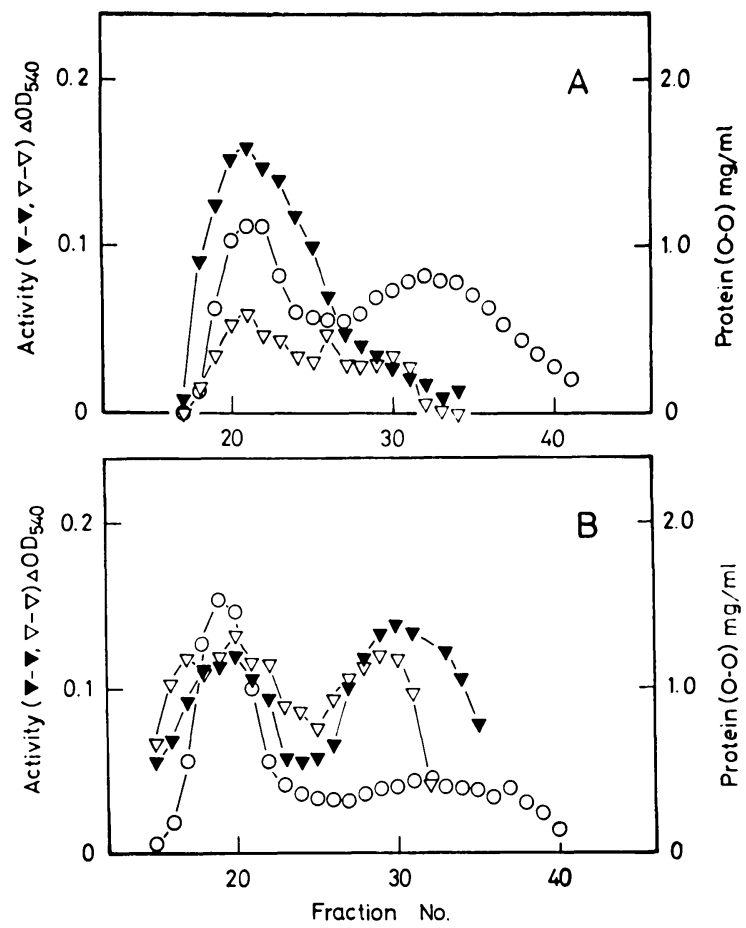

Fig. 4. Elution patterns of PDHase activity from Sephadex G-200 column in $\mathrm{KGa}$ (wild type) (A) and 508a (ace-4) (B). $\quad \mathbf{\nabla}$, PDHase activity in the absence of ATP; $\nabla$, PDHase activity in the presence of ATP $(5 \mathrm{mM})$. 
Pyruvate dehydrogenase. PDHase activities of the PDHC-deficient mutant and the wild type strains are shown in Table 3. Every mutant had weak activity compared with the wild type strain, KGa. Characteristically in 508a, PDHase activity in the M22S fraction was higher than that in the M5-22P fraction. This point is clearly shown by Sephadex G-200 gel chromatographic pattern of PDHase activity (Fig. 4). In the wild type strain, $\mathrm{KGa}$, PDHase activity was eluted from the column only at void volume, and this activity was inhibited by ATP (Fig. 4A). Inhibition of PDHase by ATP had been shown in beef kidney by Linn et al. (1969). On the contrary, PDHase of the strain 508a (ace-4) was eluted at two peaks (Fig. 4B). The first peak was at the void volume like the wild type, but this activity was not inhibited by ATP. The second peak was at fraction 30 . The molecular weight of the enzyme at this peak was estimated at about 190,000 from a comparison with Sephadex G-200 chromatographic pattern of standard proteins (Fig. 5). Both 511a (ace-2) and 536a (ace-3) had weak PDHase activity mainly at void volume.

Lipoate acetyltransferase. LATase activities of PDHC-deficient mutant and the wild type strains are shown in Table 3. The activity in ace-4 was lower than that in the other strains. Sephadex G-200 gel chromatographic pattern of LATase was investigated. LATase activity of the wild type strain, $\mathrm{KGa}$, was obtained at void volume (peak L) and at fraction 27 (peak S), which had lower activity than peak L (Fig. 6A). The LATase activity of the ace-4 strain, 508a, was obtained at fraction 27 (peak S) with the same level as the wild type. The peak $\mathrm{L}$, however, was deficient almost perfectly in 508a (Fig. 6B). Owing to the presence of peak S, 508a had low LATase activity (Table 3). The molecular weight of the enzyme at peak $\mathrm{S}$ was estimated at about 300,000 (Fig. 5). LATase at peak $\mathrm{S}$ of $\mathrm{KGa}$ and $508 \mathrm{a}$ was compared qualitatively. The $\mathrm{Km}$ value for DL-dihydrolipoamide was calculated to be $29 \mathrm{mM}$ in

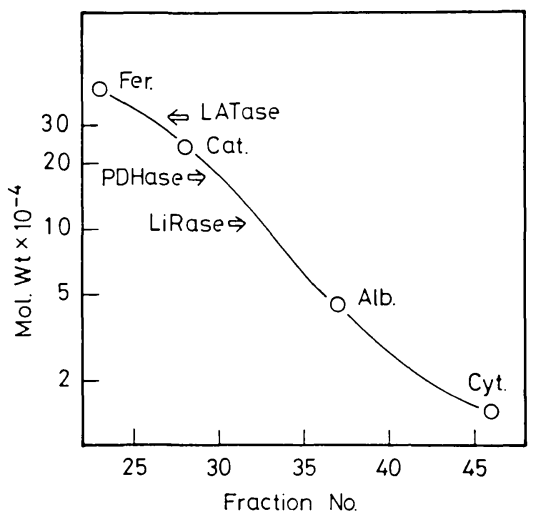

Fig. 5. Estimation of the molecular weights of PDHase, LATase and LiRase. Logarithms of the molecular weights of marker proteins were plotted against fraction number after chromatography on Sephadex G-200 column. Fer, Ferritin; Cat, Catalase; Alb, Hen egg albumin; Cyt, Cytochrome C. 

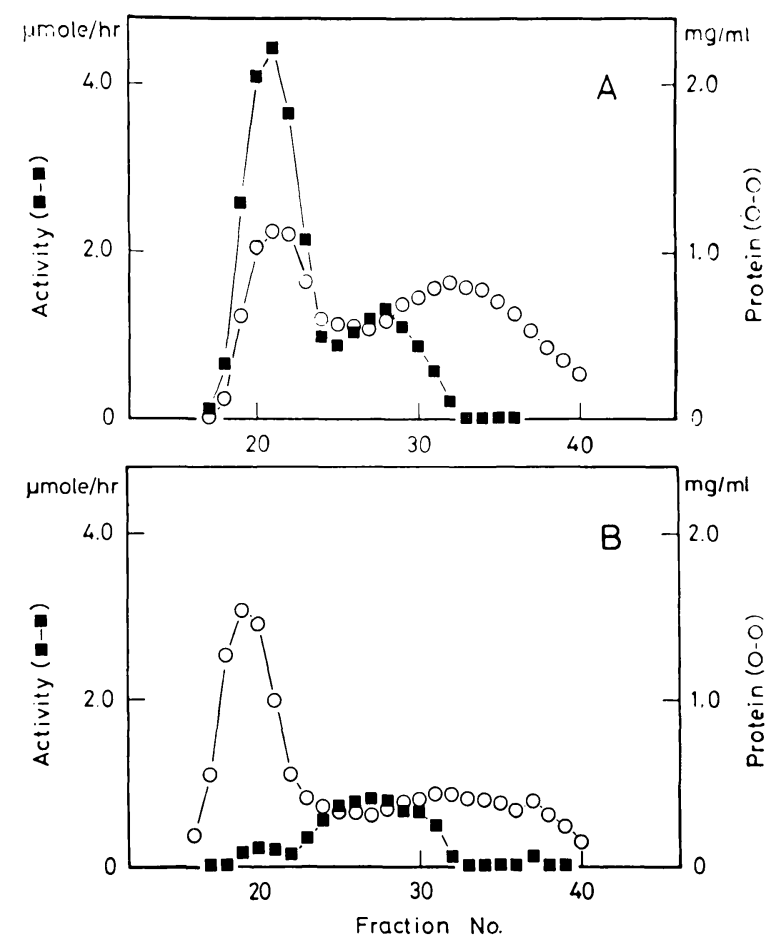

Fig. 6. Elution patterns of LATase activity from Sephadex G-200 column in $\mathrm{KGa}$ (wild type) (A) and 508a (ace-4) (B).

Table 3. Activities of component enzymes of PDHC

\begin{tabular}{|c|c|c|c|c|c|}
\hline \multirow{3}{*}{ Strain (Genotype) } & \multicolumn{5}{|c|}{ Specific activity $(\mu$ moles $/ \mathrm{mg}$ protein/h) } \\
\hline & \multicolumn{2}{|c|}{$\begin{array}{c}\text { Pyruvate } \\
\text { dehydrogenase }\end{array}$} & \multirow{2}{*}{$\begin{array}{c}\begin{array}{c}\text { Lipoate } \\
\text { acetyl- } \\
\text { transferase }\end{array} \\
\text { M5S }\end{array}$} & \multicolumn{2}{|c|}{ Lipoamide reductase } \\
\hline & M5-22P & M22S & & M5-22P & M22S \\
\hline $511 \mathrm{a} \quad($ ace -2$)$ & 0.30 & 0.06 & 4.3 & 4.8 & 7.2 \\
\hline $536 \mathrm{a} \quad($ ace -3$)$ & 0.20 & 0.03 & 8.0 & 11.4 & 11.4 \\
\hline $508 \mathrm{a} \quad($ ace -4$)$ & 0.09 & 0.18 & 1.1 & 5.4 & 11.4 \\
\hline KGa (wild type) & 1.12 & 0.37 & 6.1 & 17.4 & 18.6 \\
\hline
\end{tabular}

both strains. A broad $\mathrm{pH}$ optimum between 8 and 9 was found in both strains. With respect to heat stability, however, enzyme from KGa and 508a were slightly different. The half-lives of the peak $\mathrm{S}$ of $\mathrm{KGa}$ and that of 508a from starvation cultures were $6 \mathrm{~min}$ and $7-8 \mathrm{~min}$, respectively, at $70^{\circ} \mathrm{C}$. Specificity of LATase in both peak $\mathrm{L}$ and peak $\mathrm{S}$ from $\mathrm{KGa}$ was also compared. Both enzymes were shown to be completely dependent on dihydrolipoamide, CoA, acetylphosphate and phosphotransacetylase. 


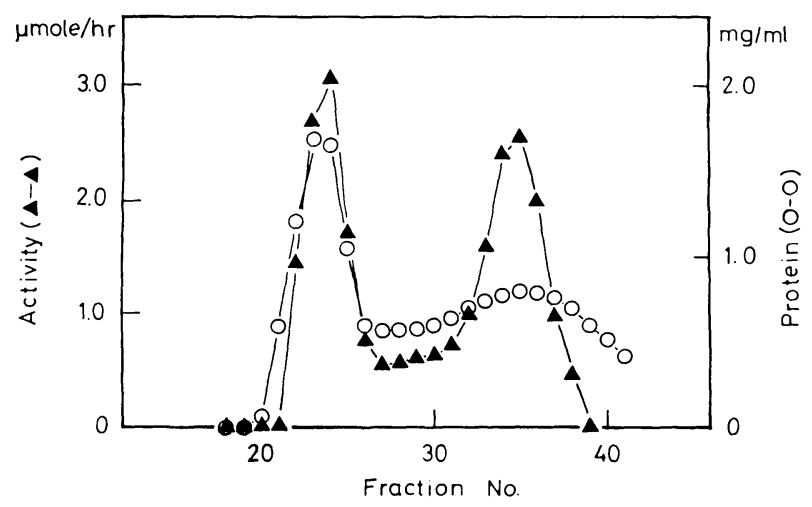

Fig. 7. Elution pattern of LiRase activity from Sephadex G-200 column in $\mathrm{KGa}$ (wild type).

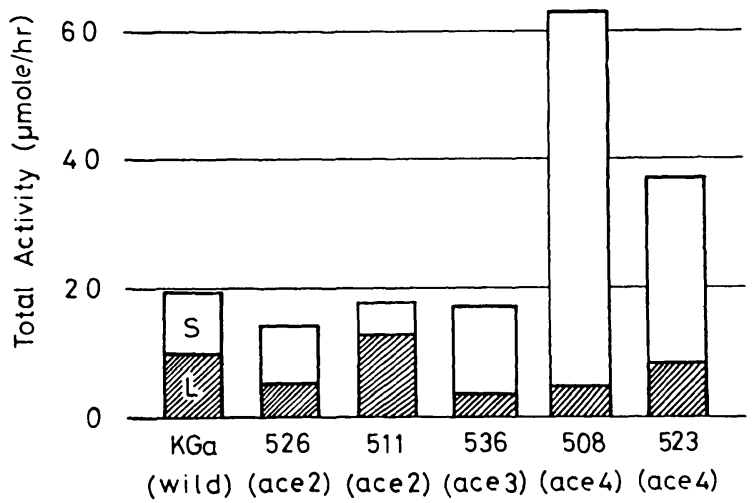

Fig. 8. Total activity of LiRase eluted from Sephadex G-200 column in various strains. L, total activity of peak L; S, total activity of peak S.

Omission of any element caused no activity. Acetyl residue was transferred to only dihydrolipoamide, and not to 2-mercaptoethanol, dithiothreitol, glutathione and L-cysteine in both peak $\mathrm{L}$ and peak $\mathrm{S}$.

Lipoamide reductase. All of the mutants deficient in PDHC activity had LiRase activity (Table 3). Qualitative difference of LiRase between the wild type and mutants was not detected in $\mathrm{Km}$ value for substrate, catalytic activity for both directions and heat stability at $70^{\circ} \mathrm{C}$. In a Sephadex G-200 gel chromatography, LiRase activity was obtained at void volume (peak L) and at fraction 35 (peak S) in the wild type (Fig. 7). The molecular weight of the peak $S$ enzyme was estimated at about 110,000 (Fig. 5). The total activity of peak $\mathrm{L}$ plus peak $\mathrm{S}$ was rather uniform in ace-2, ace-3 and the wild type. In contrast to these strains, higher total activity was detected in ace-4 mutants; the activity of peak S was increased (Fig. 8). 


\section{DISCUSSION}

Acetate-requiring mutants would be expected to have deficiencies in the carbohydrate metabolism concerned with energy production and the syntheses of precursors for many cellular components. Really, PDHC-deficient strains have been found in acetate-requiring mutants in Escherichia coli (Henning et al. 1964; Guest 1974), Salmonella typhimurium (Langley and Guest 1974) and Aspergillus nidulans (Payton et al. 1977). We identified three classes of mutants as deficient in PDHC activity among acetate mutants of Neurospora crassa (Table 1).

Characteristics of PDHC in crude Neurospora extract were similar in many respects to the purified enzyme by Harding et al. (1970) and Wieland et al. (1972). Repression of PDHC by acetate was common property both in $N$. crassa (Fig. 1) and in E. coli (Dietrich and Henning 1970), while PDHC of A. nidulans was not repressed by acetate (Payton et al. 1977).

All the heterokaryons, which showed positive complementation in growth on minimal medium (Fig. 3), showed significant levels of PDHC activity. The combination $508 \mathrm{a}+523 \mathrm{a}$ showed intra-genic complementation, and would be expected to form hybrid enzyme. The PDHC activity was recovered in vitro by mixing cell-free extracts in six combinations among nine complemented in vivo (Table 2). The component enzymes would readily be aggregated to form active PDHC in these combinations.

Each of the three component enzymes of PDHC was detected as two peaks by Sephadex G-200 gel chromatography. On of them eluted from Sephadex column at void volume comprises high molecular weight aggregate. In the case of the wild type strain, it may be PDHC itself. The other peak comprises the activity due to free component enzyme. Molecular weights of the three component enzymes of PDHC, PDHase, LATase and LiRase were about 190,000,300,000 and 110,000, respectively (Fig. 5). These values are similar to those of $E$. coli enzymes except for LATase (Eley et al. 1972).

The ferricyanide assay is rather nonspecific method for PDHase, since other enzymes also catalyze oxidative decarboxylation of pyruvate. And yet, Payton et al. (1977) failed to assay PDHase activity using ferricyanide as an electron acceptor. Using Sephadex G-200 gel chromatography, however, we detected two PDHase peaks by this method. Presumably, one is attributable to PDHC and the other is free component enzyme (Fig. 4).

The activities of all component enzymes were detected in ace-2 and ace-3 mutants (Table 3), and we were unable to conclude which components were affected in these two mutant classes. The products of the genes ace-2 and ace-3 might be some proteins existing in PDHC and have some regulatory roles. In fact, Wieland et al. (1972) reported that Neurospora PDHC contains regulatory kinase and phosphatase subunits.

It is sure that the mutations in ace-4 gene affect LATase, although ace-4 mutants had low level of LATase activity owing to the presence of peak $\mathrm{S}$ (Table 3, Fig. 6). There may be three possibilities for the existence of peak S. The first possibility is that Neurospora has two LATase isozymes and peak $\mathrm{S}$ is one of them, which is not the component of PDHC. Really, there are at least three thioltransacetylase isozymes 
in Clostridium kluyveri and in pigeon liver, and two of them can transfer the acetyl residue of acetyl-CoA to 2-mercaptoethanol besides dihydrolipoamide (Brady and Stadtman 1954). In our case, however, peak $S$ had strict substrate specificity and did not catalyze the reaction transferring acetyl residue to 2-mercaptoethanol. So, we did not consider that peak $\mathrm{S}$ is unrelated activity of LATase component of PDHC.

The second possibility is that ace-4 is the structural gene for LATase. Then, ace-4 mutant has LATase activity but the protein changed qualitatively, so that it does not aggregate to molecular weight of more than 300,000 . It has been shown in various organisms that LATase consists the core of PDHC (Ishikawa et al. 1966; Hayakawa et al. 1969; Reed and Cox 1970). Since the core of PDHC is not formed, the free components, PDHase and LiRase, were detected large quantities only in ace-4 mutants (Fig. 4, Fig. 8). Although $\mathrm{Km}$ value and $\mathrm{pH}$ optimum were not different between peak $\mathrm{S}$ of the wild type and that of ace-4, there was a little difierence in heat stability. This seems to support the second possibility.

The third possibility is that the ace-4 gene is the structural gene for some protein which makes LATase subunits aggregate to form the core of PDHC, and LATase per se is normal in ace-4 mutants. There are not too much differences between peak $\mathrm{S}$ of the wild type and that of ace-4 mutants. This could be taken to suggest that ace-4 is not the structural gene for LATase.

Although neither the second nor the third possibility is decisive at this stage, it seems to be sure that the mutations in ace- 4 gene affected LATase not to aggregate as the core of PDHC.

\section{ACKNOWLEDGMENTS}

The authors wish to thank Mr. Koji Tokuda for his technical assistance in some of the experiments.

\section{LITERATURE CITED}

Barrera, C. R., G. Namihira, L. Hamilton, P. Munk, M. H. Eley, T. C. Linn, and L. J. Reed, $1972 \alpha$-Keto acid dehydrogenase complexes. XVI. Studies on the subunit structure of the pyruvate dehydrogenase complexes from bovine kidney and heart. Arch. Biochem. Biophys. 148: $343-358$.

Brady, R. O., and E. R. Stadtman, 1954 Enzymatic thioltransacetylation. J. Biol. Chem. 211: 621-629.

Dietrich, J., and U. Henning, 1970 Regulation of pyruvate dehydrogenase complex synthesis in Escherichia coli K12. Identification of the inducing metabolite. Eur. J. Biochem. 14: 258269.

Eley, M. H., G. Namihira, L. Hamilton, P. Munk, and L. J. Reed, $1972 \alpha$-Keto acid dehydrogenase complexes. XVIII. Subunit composition of the Escherichia coli pyruvate dehydrogenase complex. Arch. Biochem. Biophys. 152: 655-669.

Guest, J. R., 1974 Gene-protein relationships of the $\alpha$-keto acid dehydrogenase complexes of Escherichia coli K12: Chromosomal location of the lipoamide dehydrogenase gene. J. Gen. Microbiol. 80: 523-532.

Harding, R. W., D. F. Caroline, and R. P. Wagner, 1970 The pyruvate dehydrogenase complex 
from the mitochondrial fraction of Neurospora crassa. Arch. Biochem. Biophys. 138: 653661.

Hayakawa, T., T. Kanzaki, T. Kitamura, Y. Fukuyoshi, Y. Sakurai, K. Koike, T. Suematsu, and M. Koike, 1969 Mammalian $\alpha$-keto acid dehydrogenase complexes. V. Resolution and reconstitution studies of the pig heart pyruvate dehydrogenase complex. J. Biol. Chem. 244: $3660-3670$.

Henning, U., C. Herz, und K. Szolyvay, 1964 Polarisation und Disproportionalität der Synthese von Enzymkomponenten des Pyruvat-Dehydrogenase-Komplexes als Mutationsfolge in Escherichia coli K12. Z. Vererbungsl. 95: 236-259.

Ishikawa, E., R. M. Oliver, and L. J. Reed, $1966 \alpha$-Keto acid dehydrogenase complexes. V. Macromolecular organization of pyruvate and $\alpha$-ketoglutarate dehydrogenase complexes isolated from beef kidney mitochondria. Proc. Natl. Acad. Sci. USA 56: 534-541.

Koike, M., L. J. Reed, and W. R. Carroll, $1960 \alpha$-Keto acid dehydrogenation complexes. I. Purification and properties of pyruvate and $\alpha$-ketoglutarate dehydrogenation complexes of Escherichia coli. J. Biol. Chem. 235: 1924-1930.

Koike, M., L. J. Reed, and W. R. Carroll, $1963 \alpha$-Keto acid dehydrogenation complexes. IV. Resolution and reconstitution of the Escherichia coli pyruvate dehydrogenation complex. J. Biol. Chem. 238: 30-39.

Kuwana, H., and R. Okumura, 1979 Genetics and some characteristics of acetate-requiring mutant strains in Neurospora crassa. Japan. J. Genetics 54: 235-244.

Langley, D., and J. R. Guest, 1974 Biochemical and genetic characteristics of deletion and other mutant strains of Salmonella typhimurium LT2 lacking $\alpha$-keto acid dehydrogenase complex activities. J. Gen. Microbiol. 82: 319-335.

Linn, T. C., F. H. Pettit, and L. J. Reed, $1969 \alpha$-Keto acid dehydrogenase complexes. X. Regulation of the activity of the pyruvate dehydrogenase complex from beef kidney mitochondria by phosphorylation and dephosphorylation. Proc. Natl. Acad. Sci. USA 62: 234-241.

Lipmann, F., and L. C. Tuttle, 1945 A specific micromethod for the determination of acyl phosphates. J. Biol. Chem. 159: 21-28.

Lowry, O. H., N. J. Rosebrough, A. L. Farr, and R. J. Randall, 1951 Protein measurement with the Folin phenol reagent. J. Biol. Chem. 193: 265-275.

Payton, M. A., W. McCullough, C. F. Roberts, and J. R. Guest, 1977 Two unlinked genes for the pyruvate dehydrogenase complex in Aspergillus nidulans. J. Bacteriol. 129: 1222-1226.

Reed, L. J., and D. J. Cox, 1970 Multienzyme complexes. In "The Enzymes" (P. D. Boyer, ed.) Vol. 1, pp. 213-240. Academic Press, New York.

Reed, L. J., M. Koike, M. E. Levitch, and F. R. Leach, 1958 Studies on the nature and reactions of protein-bound lipoic acid. J. Biol. Chem. 232: 143-158.

Reed, L. J., and C. R. Willms, 1966 Purification and resolution of the pyruvate dehydrogenase complex (Escherichia coli). In "Methods in Enzymology" (W. A. Wood, ed.) Vol. 9, pp. 247265. Academic Press, New York.

Vogel, H. J., 1964 Distribution of lysine pathways among fungi: Evolutionary implications. Amer. Naturalist 98: 435-446.

Wais, U., U. Gillmann, und J. Ullrich, 1973 Regulation, Isolierung und Charakterisierung des Pyruvat-Dehydrogenase-Komplexes aus Hefe. Hoppe-Seyler's Z. Physiol. Chem. 354: 206.

Wieland, O. H., U. Hartmann, and E. A. Siess, 1972 Neurospora crassa pyruvate dehydrogenase: Interconversion by phosphorylation and dephosphorylation. FEBS Letters 27: 240-244. 